\title{
POST-THATCHER FiscAL STRATEGIES IN THE U.K.: AN INTERPRETATION
}

\author{
ANDREW HuGHES HALLETT \\ CESIFO WORKING PAPER NO. 1372 \\ CATEGORY 5: Fiscal POLICY, MACROECONOMICS AND GROWTH \\ DECEMBER 2004
}

Presented at the CESIFo/LBI Conference on the Sustainability of Public Debt, OCTOBER 2004

- from the CESifo website: www. CESifo.de 


\title{
POST-THATCHER FisCAL STRATEGIES IN THE U.K.: AN INTERPRETATION
}

\begin{abstract}
Fiscal policy in Britain has changed radically since the Keynesianism of the 1960s and 1970s. After a passive period under monetarism of the 1980s, fiscal policy is said to have adopted a leadership role with long term objectives (low debt, the provision of public services/ investment, and social equity), together with an independent central bank. Monetary policy, operating with instrument independence, then takes care of short run stabilisation. I test this view - confronting it with evidence from the institutional arrangements put in place since 1997; with econometric evidence from the policy responses themselves; and with theoretical evidence on the incentive to choose such a regime in the first place. I conclude that this claim is broadly correct. It appears that the UK's improved performance is a consequence of the advantages of combining fiscal leadership with an (instrument) independent central bank. The key feature is the ability to trade target (not instrument) independence in monetary policy to secure greater coordination between fiscal and monetary strategies.
\end{abstract}

JEL Code: E52, E61, F42.

Keywords: Stackelberg leadership, policy complementarity, institutional coordination.

\author{
Andrew Hughes Hallett \\ Vanderbilt University \\ Department of Economics \\ Nashville, TN 37235-1819 \\ USA \\ a.hugheshallett@vanderbilt.edu
}

I am grateful for comments from Gottfried Haber and participants at the CESifo-LBI Conference on the Sustainability of Public Debt, and to Petra Geraats, Sean Holly and others at Cambridge University. The policy response functions in section 4 were developed in conjunction with John Lewis of the Bank of Estonia; and the model used in section 5 is adapted from my work with Diana Weymark at Vanderbilt University. Neither is responsible for my interpretation of events. 


\section{Introduction: British Fiscal Policy to 2004:}

British fiscal policy has changed radically since the days when it tried to micro-manage all of aggregate demand with an accommodating monetary policy in the 1960s and 1970s; and again from the 1980s when it was passive but set to strengthen the economy's supply side responses, while monetary policies actively pursued low inflation and stable growth.

The 1990s saw a return to more activist fiscal policies - but policies designed strictly in combination with an equally active monetary policy based on inflation targeting and an independent Bank of England. They are set, in the main, to gain a series of medium to long term objectives - low debt, the provision of public services and investment, social equality and economic efficiency. The income stabilising aspects of fiscal policy have therefore been left passive, to act through the automatic stabilisers which are part of any fiscal system, and the discretionary part (the bulk of the policy measures) is set to achieve those longer term objectives - including balancing the budget, bar public investment projects, over the cycle. Monetary policy, meanwhile, is intended to take care of any short run stabilisation around the cycle; beyond what, predictably, would be done by the automatic stabilisers. ${ }^{1}$

To draw a sharp distinction between actively managed long run policies, and short run stabilisation efforts restricted to the automatic stabilisers, is of course the strategic policy prescription recommended by Taylor (2000). Marrying that with an activist monetary policy directed at cyclical stabilisation, but based on an independent Bank of England and a monetary policy committee with instrument (but not target) independence, appears to have been the distinctive UK feature. It implies a leadership role for fiscal policy which

\footnotetext{
${ }^{1}$ The Treasury estimates that the automatic stabilizers will, in normal circumstances, stabilize $30 \%$ of the cycle; the remaining $70 \%$ is left to monetary policy (HM Treasury, 2003). The option to undertake discretionary stabilizing interventions is retained "for exceptional circumstances" however. Nevertheless, the need for any such additional interventions is unlikely: first, because of the effectiveness of the forward looking, symmetric and activist inflation targeting mechanism adopted at the Bank of England; and, second, because the longer term expenditure (and tax) plans are deliberately constructed in nominal terms so that they add to the stabilizing power of the automatic stabilizers in more serious booms or slumps.
} 
allows fiscal and monetary policies to be better coordinated -- but without either losing their ability to act independently. ${ }^{2}$

In short, Britain has adopted a Stackelberg solution which lies somewhere between the discretionary (but Pareto superior) cooperative solution, and the fully independent (but noncooperative) solution. Nonetheless, proper management is required. By forcing the focus onto long run objectives, to the exclusion of the short term, this set up has imposed a degree of precommitment (and potential for electoral punishment) because governments naturally wish to lead but the regime remains noncooperative so that there is no incentive to renege on earlier plans in the absence of changes in information. Thus the policies and intended outcomes will be sustained by the government of the day. ${ }^{3}$ In any event, British

Table 1: The UK's Fiscal Performance Relative to the EU-12

\begin{tabular}{|l|l|l|l|l|l|}
\hline & $\begin{array}{l}\text { HICP } \\
\text { Inflation (\%) }\end{array}$ & $\begin{array}{l}\text { Output } \\
\text { Growth (\%) }\end{array}$ & $\begin{array}{l}\text { Deficit } \\
\text { Ratio (\%) }\end{array}$ & $\begin{array}{l}\text { Debt } \\
\text { Ratio (\%) }\end{array}$ & $\begin{array}{l}\text { unemploy- } \\
\text { ment (\%) }\end{array}$ \\
\hline $\mathbf{1 9 9 9}$ & 1.3 & 3.6 & +1.1 & 45.1 & 5.9 \\
UK & 1.1 & 2.8 & -1.3 & 72.5 & 9.4 \\
EU-12 & & & & & \\
\hline $\mathbf{2 0 0 0}$ & 1.0 & 3.5 & +2.7 & 42.1 & 5.3 \\
UK & 2.1 & 3.5 & +0.2 & 70.1 & 8.5 \\
EU-12 & & & & & \\
\hline $\mathbf{2 0 0 1}$ & 0.8 & 2.3 & +0.9 & 38.9 & 5.2 \\
UK & 2.3 & 1.6 & -1.7 & 69.5 & 8.0 \\
EU-12 & 1.2 & 1.8 & -1.6 & 38.5 & 5.1 \\
\hline $\mathbf{2 0 0 2}$ & 2.3 & 0.9 & -2.4 & 69.4 & 8.4 \\
UK & 1.3 & 2.2 & -3.2 & 39.8 & 5.0 \\
EU-12 & 2.1 & 0.5 & -2.7 & 70.7 & 8.9 \\
\hline $\mathbf{2 0 0 3}$ & & & & \\
UK & 1.3 & 3.5 & -2.9 & 39.8 & 4.7 \\
EU-12 & 2.3 & 2.0 & -2.8 & 70.6 & 9.0 \\
\hline $\mathbf{2 0 0 4}$ & & & & \\
UK & & & & & \\
EU-12 & & &
\end{tabular}

\footnotetext{
${ }^{2}$ For details on how this leadership vs. stabilization assignment is intended to work, see HM Treasury (2003) and section 3 below. Australia and Sweden operate rather similar regimes. But their arrangements differ in a number of important technical details which affect the degree of coordination that emerges, and hence in the outcomes and strength of commitment to the given path and policies.

${ }^{3}$ Stackelberg games, with fiscal policy leading, produce fiscal commitment: that is, subgame per-fection with either strong or weak time consistency (Basar, 1989). In that, we have "rules rather than discretion". Commitment to the stabilization policies is then assured by the independent monetary authority.
} 
fiscal policy has been relatively successful under this regime. It has been more successful than that in her European partners, as table 1 shows, and arguably at least as successful as in the US, Canadian or Australian economies. So it is not that fiscal policy was not used. The evidence suggests that it has been used more effectively to produce lower debt, more stable incomes and employment, but without any additional inflation.

\section{The hypothesis in this paper}

The hypothesis advanced in this paper is that the UK's improved performance is due to the fact that fiscal policy leads an independent monetary policy. This leadership derives from the fact that fiscal policies typically have long run targets (sustainability, low debt), and is not easily reversible (public services, social equality), and doesn't stabilise well if efficiency is to be maintained. Nevertheless, there are also automatic stabilisers in any fiscal policy framework, implying that monetary policy must condition itself on the fiscal stance at each point. That puts the latter in a follower's role. This is all to the good, however, because it allows the economy to secure the benefits of an independent monetary policy; but also enjoy a certain measure of coordination between the two sets of policy makers - discretionary/automatic fiscal policies on one side, and active monetary policies on the other. The extra coordination in this case arises because the constraints on, and responses to an agreed leadership reduce the externalties of self-interested behaviour which independent agents impose on one another. That allows a Pareto improvement over the conventional noncooperative (full independence) solution, without reducing the central bank's ability to act independently. ${ }^{4}$

To show that UK fiscal policy does lead monetary policy in this sense, and that that is the reason for the Pareto improved results in table 1, I produce evidence in three parts:

\footnotetext{
${ }^{4}$ A common inflation target will take this process further in the case of Britain, as I have argued elsewhere (Hughes Hallett, 1998). But is not an essential point once the coordinating elements of leadership are put in place since a tighter target at the central bank will cause its reaction function to shift. The government, as leader, will incorporate that change into its own decision making and then re-optimise to offset it (Hughes Hallett and Weymark,2004a).
} 
- Institutional evidence: taken from the UK Treasury's own assessment of how its policies work, what goals it needs to achieve, and how the monetary stance may affect it or vice versa,

- Empirical evidence: how monetary policy is affected by fiscal, but fiscal with its longer objectives does not depend on monetary policies,

- Theoretical evidence: which shows how, with different goals for governments and central banks, Pareto improving results can be expected to emerge from fiscal leadership. The UK has therefore had the incentive, and the capacity, to operate in this way.

\section{Institutional Evidence: The Treasury's Mandate}

History: British fiscal policy has changed a great deal over 30 years. It is no exaggeration to say that fiscal policy was the principle instrument of economic policy in the 1960s and 1970s, and was focused almost exclusively on demand management. Monetary policy and the provision of public services (subject to a lower bound) were essentially accommodating factors since the main constraint was perceived to be the financing of persistent current account trade deficits. The result of this was a short term view, in which the conflicts between the desire for growth (employment) and the recurring evidence of overheating (trade deficits) led to an unavoidable sequence of "stop-go" policies. There were many ${ }^{5}$ who argued that the real problem was a lack of long run goals for fiscal policy; and that the lags inherent in recognizing the need for a policy change and in implementing it through Parliament till it takes hold in the markets, had produced a system that was actually destabilizing rather than stabilizing. But there would have been conflicts anyway because there were two or more competing goals, but effectively only one instrument to reach them.

Such a system could not provide the longer run goal of public services, public investment and social equity. It certainly proved too difficult to turn fiscal policy on and off as fast

\footnotetext{
${ }^{5}$ Dow (1964); also Radcliffe (1959), Plowden (1961), Prest (1968), Price (1978), Hatton - Chrystal (1991).
} 
and frequently as required, and pre-commit to certain expenditure and taxation plans at the same time. The point here is that, if you cannot precommit fiscal policy to certain goals, you won't be able to precommit monetary policy either. That means the "stable growth with low inflation objective" will be lost. Valiant attempts to avoid this problem by imposing longer run goals and greater coherence on the Treasury's policy making through the Department of Economic Affairs (1960s), and again with the Social Contract in the 1970s, or by introducing an additional instrument (prices and incomes policies) when the supply side began to slide into "stagflation", all failed because they did nothing to redress the balance between the short run (demand management) and the long run (services, social equity, competitiveness); or between the growth objective and the nooverheating objective. Indeed it would have been difficult to do so with the breakdown of the Phillips curve trade-off between those two objectives.

In the 1980s, the strategy changed when a new regime took office with the aim of reducing the size and role of the government in the economy. The demand management role of fiscal policy was phased out. That role passed over to inflation control and monetary management - with limited success in the earlier phases of monetary and exchange rate targeting, but with rather more success when it was formalized as an inflation targeting regime with an independent Bank of England and monetary policy committee. In this period, therefore, the role of fiscal policy was to provide the "conditioning information" within which monetary management had to work. It was split into two distinct parts. Short term stabilization of output and employment was left to the automatic stabilizers inherent in the prevailing tax and expenditures regime. Discretionary adjustments would only be used in exceptional circumstances, if at all ${ }^{6}$. The rest of fiscal policy, being the larger part, was then directed at longer term objectives: in this instance, making changes to free up the supply side (and enhance competitiveness) on the argument that greater microeconomic flexibility would both reduce the need for stabilizing interventions (since relative wage and price adjustments would do the job better), and also provide the conditions for stronger employment and

\footnotetext{
${ }^{6}$ This follows the recommendations in Taylor (2000). However, because of the inevitable trade-off between cyclical stability and budget stability, it likely to be successful only in markets with sufficiently flexible wages and prices (Fatas et al, 2003).
} 
growth (HMT 2003). Given that, the longer run goals of better public services, efficiency and social equity could then be attained. Moreover, as the market flexibility changes were made, this part of fiscal policy could be increasingly focused on providing the longer run goals directly. And that, broadly, is how fiscal policy is now conducted in the UK. ${ }^{7}$

Now: According to the Treasury's own assessment (HMT, 2003), UK fiscal policy now leads monetary policy in two senses. First, fiscal policy is decided in advance of monetary or other policies (pp. 5, 63, 64, 74) ${ }^{8}$, and with a longer time horizon (pp. 5, 42, $48,61)$. Second, monetary policy is charged with controlling inflation and stabilizing output around the cycle - rather than steering the economy as such (pp. 61-63). Fiscal policy therefore sets the conditions within which monetary has to respond and achieve its own objectives (pp. 9, 15, 67-8). The short term fiscal interventions, less than half the total and declining (p. 48, box 5.3, section 6), are restricted to the automatic stabilizers with effects that are known and predictable. The short run discretionary components have become negligible (p. 59, table 5.5), and the long run objectives of policy will always take precedence in cases of conflict (pp. 61, 63-8). Fiscal policy would therefore not be used for fine tuning (pp. 11,63) or for stabilization (pp. 1, 14). That burden will be carried by interest rates, given the fiscal stance and its forward plans (pp. 1, 7, 11,37).

Third, given the evidence that consumers and firms often do not look forward efficiently, and may anyway be credit constrained, and also that the impacts of fiscal policy are uncertain and have variable lags (pp. 19, 26, 48; Taylor, 2000), it makes sense for fiscal policy to be used consistently and sparingly and in a way that is clearly identified with the long term (not short run) objectives. The UK has determined these objectives to be (pp. 1-4, 11-13, 39-41, 61-3, 81-2):

- The achievement of sustainable public finances in the long term; low debt $(40 \%$ of GDP); and symmetric stabilization over the cycle.

\footnotetext{
${ }^{7}$ This summary is taken from the UK Treasury's own view (HMT, 2003), sections 2, 4 and pp 34-38.

${ }^{8}$ In this section, page or section numbers given without further reference are all taken from HMT (2003).
} 
- A sustainable and improving delivery of public services (health and education); improving competitiveness/supply side efficiency in the long term; the preservation of social (and inter-generational) equity and alleviation of poverty.

- Recognition that the achievement of these objectives is often contractual and cannot easily be reversed once committed. The long lead times needed to build up these programmes mean that the necessary commitments must be made well in advance. Frequent changes would conflict with the government's medium term sustainability objectives, and cannot be made. Similarly, changes in direct taxes will affect equity and efficiency, and should seldom be made.

- The formulation of clear numerical objectives consistent with these goals; a transparent set of institutional rules to achieve them; and a commitment to a clear separation of these goals from economic stabilization around the cycle to be achieved by automatic stabilizers combined with monetary policy. ${ }^{9}$

- To ensure fiscal policy can operate along these lines, public expenditures are planned with fixed three year Departmental Expenditure Limits ${ }^{10}$ which, combined with decision and implementation lags of up to two years, means that the bulk of fiscal policy has to be planned with a horizon of up to five years versus a maximum of two years in the inflation targeting rules operated by the Bank of England. Moreover, these spending limits are constraints defined in nominal terms, so they will be met. In addition the Treasury operates a tax smoothing approach -- having rejected "formulaic rules" that might have adjusted taxes or expenditures, or the various tax regulators or credit taxes that could have stabilized the economy in the short term. The bulk of fiscal policy will remain focused on the medium to long term therefore.

In summary, the institutional structure itself has introduced fiscal leadership. And, since

\footnotetext{
${ }^{9}$ The credibility of fiscal policy, and by extension the independent monetary policy, is seen as depending on these steps, and on symmetric stabilisation. See also Dixit (2001), Dixit and Lambertini (2003).

${ }^{10}$ The model for this appears to be the Australian Charter of Budget Honesty which has a horizon of four years rather than three for expenditure plans.
} 
the discretionary elements are smaller than elsewhere -- and smaller than the automatic stabilizers (tables 5.1-5.3) and declining (box 5.3) -- something else (monetary policy) must have taken up the burden of short run stabilization. This arrangement is therefore best modeled as a Stackelberg game, with institutional parameters for goals, independence, priorities etc. We shall argue that this has had the very desirable result of increasing the degree of coordination between policy makers without compromising their formal or institutional independence - or indeed their credibility for delivering stability and low inflation, free of political pressures for short term results. Constrained independence, in other words, designed to reduce the externalities which each party might impose on the other.

\section{Empirical Evidence: the "Leadership with Separation" Model}

The next step is to establish whether the UK authorities actually have followed the "leadership with separation" model described above. The fact that they say that they follow such a strategy does not mean that they succeed in doing so in practice. The difficulty here is that, although the asymmetry in ex-ante (anticipated) responses between follower and leader - the follower expects no further changes from the leader after the follower chooses his reaction function, whereas the leader takes that reaction function into account - is clear enough in the theory, such an asymmetry and zero restriction will not appear in the ex-post observed responses that emerge in the final solution. ${ }^{11}$ Since we have no data on anticipations, this makes it very difficult to test for leadership directly in the outcomes. But we can use indirect tests based on the degree of competition, or otherwise, between instruments.

a) Monetary Responses in Britain and Europe: For monetary policy, it is widely argued that the authorities' decisions can best be modelled by a Taylor rule ${ }^{12}$

\footnotetext{
${ }^{11}$ See Basar and Olsder (1999), Hughes Hallett (1984), Brandsma and Hughes Hallett (1984).

${ }^{12}$ One can argue that policy should be based on fully optimal rules (Svensson, 2003), of which (1) will be one special case. But it is hard to argue that policy makers actually do optimise when the additional gains from doing so may be small; and when the uncertainties in their information, monetary transmissions or the economy's responses may be quite large. In practice, therefore, the Taylor rule approach has been found to fit central bank behaviour better.
} 


$$
r_{t}=\rho r_{t-1}+\alpha E_{t} \pi_{t+k}+\beta g a p_{t+h} \quad \alpha, \beta, \rho \geq 0
$$

where $\mathrm{k}, \mathrm{h}$ represent the authorities' forecast horizon ${ }^{13}$, and may be positive or negative. Normally $\alpha>1$ will be required to avoid indeterminancy: that is, arbitrary variations in output or inflation as a result of unanchored expectations in the private sector (Woodford, 2003). The relative size of $\alpha$ and $\beta$ then reveals the authorities' preference for inflation control vs. income stabilisation; and $\rho$ their preference for gradualism. We set $\mathrm{h}=0$, since monetary policy appears to depend only on the inflation horizon (Dieppe et al, 2004).

In order to obtain an idea of the influence of fiscal policy on monetary policy in practice, I include some Taylor rule estimates - with and without fiscal variables - in table 2(a). They show such rules for the UK and the Eurozone since 1997 and 1999; that is since new monetary regimes were introduced in each case. The Eurozone has been included to emphasise the contrast between fiscal leadership in the UK, and the lack of it in Europe.

\section{Table 2(a): Generalised Taylor Rules in the UK and EU-12}

Dependent variable: central bank lending rate $r_{t}$ :

For the UK, monthly data from $1997.06-2004.01$

\begin{tabular}{|l|l|l|l|l|l|l|l|}
\hline & const & $r_{t-1}$ & $\pi_{j, k}^{e}$ & $\mathrm{j}, \mathrm{k}$ & gap & $\mathrm{pd}$ & debt \\
\hline 1$)$ & -1.72 & 0.711 & 1.394 & $+6,+18$ & 0.540 & - & - \\
& $(2.16)$ & $(5.88)$ & $(2.66)$ & & $(2.06)$ & & \\
\hline
\end{tabular}

\begin{tabular}{rl|l|l|l|l|l|l|}
\hline 2$)$ & -2.57 & 0.598 & 1.289 & $+9,+21$ & 1.10 & -0.67 & 0.43 \\
& $(2.59)$ & $(4.38)$ & $(0.66)$ & & $(1.53)$ & $(0.83)$ & $(0.50)$ \\
\hline
\end{tabular}

\footnotetext{
${ }^{13}$ In principle, $\mathrm{k}$ and $\mathrm{j}$ may be positive or negative: positive if the policy rule is based on future expected inflation, to head off an anticipated problem, as in the Bank of England. But negative if interest rates are to follow a feedback rule to correct past mistakes or failures. Or a combination of both: $E \pi_{t+j, t+k}$.
} 
For the Eurozone (EU-12), monthly data from $1999.01-2004.01$

\begin{tabular}{|l|l|l|l|l|l|l|l|}
\hline & const & $r_{t-1}$ & $\pi_{j, k}^{e}$ & $\mathrm{j}, \mathrm{k}$ & gap & $\mathrm{pd}$ & $\mathrm{debt}$ \\
\hline 1$)$ & -0.996 & 0.274 & 1.714 & $+9,+21$ & 0.610 & - & - \\
& $(0.76)$ & $(1.04)$ & $(3.89)$ & & $(1.77)$ & & \\
\hline
\end{tabular}

\begin{tabular}{rl|l|l|l|l|l|l|}
\hline 2$)$ & -13.67 & 0.274 & 1.110 & $-6,+6$ & 0.341 & 0.463 & 0.191 \\
& $(0.59)$ & $(1.04)$ & $(1.19)$ & & $(1.22)$ & $(2.89)$ & $(0.63)$ \\
\hline
\end{tabular}

Notation: $\mathrm{j}, \mathrm{k}$ give the Bank's inflation forecast interval; $\pi_{j, k}^{e}$ represents the average inflation rate expected over the interval $\mathrm{t}+\mathrm{j}$ to $\mathrm{t}+\mathrm{k}: E \pi_{t+j, t+k}$; gap $=$ GDP - trend GDP; $\mathrm{pd}$ $=$ primary deficit/surplus as a percentage of GDP (a surplus $>0$ ); debt $=$ debt/GDP ratio. Estimation: instrumented 2SLS; t-ratios in parentheses; $\mathrm{j}$, k determined by search; and the output gap is obtained from a conventional HP filter to determine trend output.

b) Different types of leadership: Conventional wisdom suggests that Europe has either monetary leadership or independent policies; and hence policies which are either jointly dependent in the usual way, or which are complementary and mutually supporting. The latter implies monetary policy tends to expand/contract whenever fiscal policy needs to expand or contract - but not necessarily vice versa when money is expanding or contracting and is sufficient to control inflation on its own. That is a weak form of monetary leadership in which fiscal policies are an additional instrument for use in cases of particular difficulty, rather than a Nash game with potentially conflicting policy aims that need to be reconciled.

More generally, leadership implies complimentarity between policy instruments in the leader's reaction function; but conflicts (competition) between them in the follower's responses ${ }^{14}$. Thus monetary leadership would imply complimentarity in the Taylor rule, but conflicts in the fiscal responses. And fiscal leadership would have complimentarity in the fiscal rule but conflicts in the monetary responses. Evidently, from section 3, we should expect Stackelberg leadership (with fiscal policy leading) in the UK, but the opposite in the Eurozone.

\footnotetext{
${ }^{14}$ The weak form of leadership allows for independence between instruments in the leaders policy rule.
} 
c) Observed behaviour: The upper equations in each panel of table 2(a) yield the standard results for monetary behaviour in both the UK and Eurozone. Both monetary authorities have targeted expected inflation more than the output gap, since the late 1990s - and with horizons of 18-21 months ahead. The ECB has been more aggressive in this respect. But, contrary to conventional wisdom, it was also more sensitive to the output gap and had a longer horizon and less policy inertia.

However, if we allow monetary policies to react to changes in fiscal stance, we get more interesting results (the lower equations). Here we see that UK monetary decisions may take fiscal policy into account, but the effect is not strong or well defined. However this model of monetary behaviour does imply more activist policies, a longer forecast horizon (up to 2 years as the Bank of England claims) and greater attention to the output gap - the symmetry in the UK's policy rule. And most important, to the extent that fiscal policy is an influence, it is as a substitute (or competitor) for monetary policy - fiscal deficits lead to higher interest rates. This is the Stackelberg part of their interaction when fiscal leads though the effect is weak, most likely because we have only 25 observations to estimate this part of the relationship. The weak influence of the debt ratio is easily understood, however. Since that is a declared long run objective of fiscal policy, it would not be necessary for monetary policy to take it into consideration. So the upshot is weak evidence for Stackelberg follower behaviour in monetary policy, easing the competition (externalities) between policy instruments.

The ECB results look quite different. Once fiscal effects are included, the concentration on inflation control is much reduced (it comes close to indeterminancy and may not even be significant) and the forecast horizon shrinks to 6 months. Moreover, a feedback element, to correct past mistakes, comes in. At the same time, output stabilisation becomes less important and less significant, which implies symmetric targeting goes out. Instead monetary policy now appears to react to fiscal policy, but with the "wrong" sign: the larger the primary deficit, the looser monetary policy. In this case therefore, the policies are acting as complements - circumstances which call for a primary deficit will 
also call for a relaxation of monetary policy. Thus we have evidence of possible monetary leadership, where fiscal policy is used as an additional policy instrument.

\section{d) Fiscal Reaction Functions in the UK and Eurozone}

A number of analysts have hypothesised that fiscal policy responses can best be modelled by means of a "fiscal Taylor rule":

$$
d_{t}=a_{t}+\operatorname{\gamma gap}_{t}+s d \quad \gamma>0
$$

where $\mathrm{sd}=$ structural deficit ratio, $d_{t}$ is the actual deficit ratio $(\mathrm{d}>0 \text { denotes a surplus })^{15}$, and $a_{t}$ represents other factors such as the influence of monetary policy, existing or anticipated inflation, the debt burden, or discretionary fiscal interventions. The coefficient $\gamma$ then gives a measure of an economy's automatic stabilisers. The European Commission (2002), for example, estimates $\gamma \approx 1 / 2$ for Europe - a little more in countries with an extensive social security system, a little less elsewhere. And a similar relationship is thought to underlie UK fiscal policy (see HMT 2003, boxes 5.2 and 6.2).

The signs of the remaining factors in $a_{t}$ are not so clear. The debt burden should increase current deficits, unless there is a systematic debt reduction programme underway. Inflation should have a positive impact on the deficit ratio if fiscal policy is used for stabilisation purposes, but no effect otherwise. Finally, the output gap should also have a positive impact on the deficit ratio if the latter is being used for stabilisation purposes - in which case interest rates should be negatively correlated with the size of the deficit because monetary policies focussed on inflation and fiscal policies focussed on short run stabilisation would conflict in the language of the previous section. Conversely, a negative association with the output gap, but a positive one with interest rates, would imply no automatic stabiliser effects but mutually supporting policies:i.e higher interest rates go with tighter fiscal policies. That implies complementary policies and closer coordination.

\footnotetext{
${ }^{15}$ The Commission actually defines $\mathrm{d}>0$ to be a deficit. They therefore expect $\gamma$ to be negative. See Taylor (2000), Galli and Perotti (2003), Canzoneri (2004), Turrini and in 't Veld (2004) for similar formulations.
} 
Table 2(b) contains our estimates of the fiscal policy reaction functions for the UK and the Eurozone. Higher debt increases the surplus ratio in the UK, but has no effect in the Euro area. So, while the UK evidently has had a systematic debt reduction programme, no such efforts have been made in that direction in Europe. Inflation, on the other hand, has had no effect on the UK deficit, but a negative one in Europe. Similarly the output gap produces a negative reaction in Europe, but a positive one in the UK. These two variables therefore indicate that fiscal policy has been used for output stabilisation in the

\section{Table 2(b): Fiscal Policy Reaction Functions ${ }^{16}$}

For the UK, sample period $1997 \mathrm{q} 3-2004 \mathrm{q} 2$

$$
d_{t}=-0.444+0.845 \text { debt }_{t}+0.0685 r_{t}+1.076 \text { gap }_{t} \quad \bar{R}^{2}=0.78, \quad F_{3,24}=33.23
$$

For the Eurozone, sample period 1999q1 - 2004q2

$$
d_{t}=3.36+1.477 d_{t-1}-0.740 \pi_{+9,21}^{e}-0.207 r_{t}-0.337 g a p_{t} \quad \bar{R}^{2}=0.95, F_{4,11}=54.55
$$

Key: $d_{t}=$ gross deficit/GDP $(\%)$, where $\mathrm{d}<0$ denotes a deficit; $d e b t_{t}=\mathrm{debt} / \mathrm{GDP}(\%)$; $r_{t}$ is the central bank lending rate; $\pi_{j, k}^{e}$ and gap $_{t}$ as in table 2(a).

Estimation method, instrumented 2SLS; linear interpolation for quarterly deficit figures; and t-ratios in parentheses.

Note: At current debt, interest rates and inflation targets, these estimates imply a structural deficit of about $0.1 \%$ for the UK and $2.6 \%$ for the Eurozone.

UK - consistent with allowing automatic stabilisers to do the job - but for purposes other than that in the Eurozone. This result fits in neatly with Europe's evident inability to save for a rainy day in the upturn, and inability to stabilise in the downturn because of the Stability Pact $^{17}$. But a value of $\gamma \geq 1$ means that the UK has had a commitment to

\footnotetext{
${ }^{16}$ Increasing the sample size back to 1994 when, according to some, the new fiscal regime really took shape, makes no material difference to our estimates of the UK equation. Similarly, replacing primary with gross deficits makes little difference. That confirms fiscal discipline was seen in terms of the overall deficit. ${ }^{17}$ See Buti et al, (2003). The presence of debt in the UK rule indicates that sustainability has been a primary target in the UK, but not in the Eurozone.
} 
something beyond stabilisation: e.g. public services or debt management. It means those commitments can be funded better in good times without reversals in bad times.

Consequently, the UK appears to use fiscal policy for stabilisation in a minor way, as claimed, while the Euro economies seem not to use fiscal policy that way at all. Confirmation of this comes from the responses to interest rate changes, which are positive but very small and statistically insignificant in the UK; but negative and just significant in Europe. That implies British fiscal policies are chosen independently of monetary policy, as claimed in our Stackelberg interpretation of the Treasury's strategy. But if there is any association, fiscal and monetary policies are compliments and hence weakly coordinated. That suggests leadership. Moreover, since monetary and fiscal policies are substitutes in the UK monetary rule, but independent or complements in the fiscal rule, fiscal policy must be the one exercising leadership.

In the Eurozone, the opposite holds. There monetary and fiscal policies are competitive in the fiscal rule, but complements in the monetary rule. That suggests weak monetary leadership; or possibly a simple noncooperative game since the complimentarity part in table 2(a) is quite small.

\section{Theoretical Evidence: A Model of Fiscal Leadership ${ }^{18}$}

\subsection{The Economic Model and Policy Constraints}

The remaining question is, would governments actually want to pursue fiscal leadership? The model used in Hughes Hallett and Weymark (2001, 2002, 2004a, b, c) provides a useful framework for analysing that question. For exposition purposes, we suppress the possible spillovers between countries and focus on the following three equations to represent the economic structure of any country:

\footnotetext{
${ }^{18}$ Our statistical evidence, by virtue of the restricted samples and that extending them across regime shifts is not an option, cannot be conclusive. We therefore need to underpin the argument with evidence that policy makers have a clear incentive to follow this leadership with separation model. Note however, that our tests are defined by the signs of the policy interactions - not their size. That means we have found no empirical evidence to reject the fiscal leadership hypothesis, and some to accept it.
} 


$$
\begin{aligned}
& \pi_{t}=\pi_{t}^{e}+\alpha y_{t}+u_{t} \\
& y_{t}=\beta\left(m_{t}-\pi_{t}\right)+\gamma g_{t}+\varepsilon_{t} \\
& g_{t}=m_{t}+s\left(b y_{t}-\tau_{t}\right)
\end{aligned}
$$

where $\pi_{t}$ is the inflation rate in period $\mathrm{t}, y_{t}$ is output growth in period $\mathrm{t}$, and $\pi_{t}^{e}$ represents the rate of inflation that rational agents expect will prevail in period $t$ conditional on the information available at the time expectations are formed. Next $m_{t}, g_{t}$, and $\tau_{t}$ represent the growth in the money supply, government expenditures, and tax revenues in period $t$; and $u_{t}$ and $\varepsilon_{t}$ are random disturbances which are distributed independently with zero mean and constant variance. All variables are defined as deviations from their long run equilibrium growth paths, and we treat trend budget variables as pre-committed and balanced. The coefficients $\alpha, \beta, \gamma, s$, and $b$ are all positive by assumption. The assumption that $\gamma$ is positive is sometimes controversial. ${ }^{19}$ However, the short-run impact multipliers derived from Taylor's (1993) multi-country estimation provide empirical support for this assumption. More important in this context, the British Treasury also works on the assumption that these multipliers are positive (HMT 2003).

According to (3), inflation is increasing in the rate of inflation predicted by private agents and in output growth. Equation (4) indicates that both monetary and fiscal policies have an impact on the output gap. The microfoundations of the aggregate supply equation (3), originally derived by Lucas (1972, 1973), are well-known. McCallum (1989) shows that aggregate demand equations like (4) can be derived from a standard, multi-period utilitymaximisation problem.

Equation (5) describes the government's budget constraint. In the interests of simplicity, we allow discretionary tax revenues to be used for redistributive purposes only, but allow discretionary expenditures for enhancing output. We further assume that there are two

\footnotetext{
${ }^{19}$ Barro (1981) argues that government purchases have a contractionary impact on output. Our model, by contrast, treats fiscal policy as important because: (i) fiscal policy is widely used to achieve redistributive and public service objectives; (ii) governments cannot pre-commit monetary policy with any credibility if fiscal policy is not pre-committed (Dixit and Lambertini, 2003); and (iii) Central Banks, and the ECB in particular, worry intensely about the impact of fiscal policy on inflation and financial stability (Dixit 2001).
} 
types of agents, rich and poor, and that only the rich use their savings to buy government bonds. In (5), $b$ is the proportion of pre-tax income (output) that goes to the rich and $s$ is the proportion of after-tax income that the rich allocate to saving. Tax revenues, $\tau_{t}$, are used by the government to redistribute income from the rich to the poor, either directly or via public services. Thus, the fiscal structure we describe has output-enhancing expenditures $g_{t}$ and transfers $\tau_{t}$. Both are financed by aggregate tax revenues; that is, from discretionary and trend revenues. Expenditures above those revenues must be financed by the sale of bonds.

Using (3) and (4) to solve for $\pi_{t}^{e}, \pi_{t}$ and $y_{t}$ yields the following reduced forms:

$$
\begin{aligned}
& \pi_{t}\left(g_{t}, m_{t}\right)=(1+\alpha \beta)^{-1}\left[\alpha \beta m_{t}+\alpha \gamma g_{t}+m_{t}^{e}+\frac{\gamma}{\beta} g_{t}^{e}+\alpha \varepsilon_{t}+u_{t}\right] \\
& y_{t}\left(g_{t}, m_{t}\right)=(1+\alpha \beta)^{-1}\left[\beta m_{t}+\gamma g_{t}-\beta m_{t}^{e}-\gamma g_{t}^{e}+\varepsilon_{t}-\beta u_{t}\right] .
\end{aligned}
$$

Solving for $\tau_{t}$ using (5) and (7), then yields

$$
\begin{aligned}
& \tau_{t}\left(g_{t}, m_{t}\right)=[s(1+\alpha \beta)]^{-1}\left[(1+\alpha \beta+s b \beta) m_{t}-(1+\alpha \beta-s b \gamma) g_{t}\right. \\
& \left.-s b \beta m_{t}^{e}-s b \gamma g_{t}^{e}+s b\left(\varepsilon_{t}-\beta u_{t}\right)\right]
\end{aligned}
$$

\subsection{Government and Central Bank Objectives}

In our formulation, we allow for the possibility that the government and an independent central bank may differ in their objectives in some significant way. In particular, we assume that the government cares about inflation stabilization, output growth, and the provision of public services (income redistribution); whereas the central bank, if left to itself, would be concerned only with the first two objectives, and possibly only the first one. We also assume that the government has been elected by majority vote, so that the government's loss function reflects society's preferences to a significant extent. 
Formally, the government's loss function is given by

$$
L_{t}^{g}=\frac{1}{2}\left(\pi_{t}-\hat{\pi}\right)^{2}-\lambda_{1}^{g} y_{t}+\frac{\lambda_{2}^{g}}{2}\left[(b-\theta) y_{t}-\tau_{t}\right]^{2}
$$

where $\hat{\pi}$ is the government's inflation target, $\lambda_{1}^{g}$ is the relative weight or importance that the government assigns to output growth, ${ }^{20}$ and $\lambda_{2}^{g}$ is the relative weight which it assigns to income redistribution. The parameter $\theta$ represents the proportion of output that the government would, ideally, like to allocate to the rich. All other variables are as previously defined.

The objectives of the central bank, however, may be quite different from those of the government. We model that as follows:

$$
L_{t}^{c b}=\frac{1}{2}(\pi-\hat{\pi})^{2}-(1-\delta) \lambda^{c b} y_{t}-\delta \lambda_{1}^{g} y_{t}+\frac{\delta \lambda_{2}^{g}}{2}\left[(b-\theta) y_{t}-\tau_{t}\right]^{2}
$$

Where $0 \leq \delta \leq 1$, and $\lambda^{c b}$ is the weight which the central bank assigns to output growth. The parameter $\delta$ measures the degree to which the central bank is forced to take the government's objectives into account when formulating monetary policy. The closer $\delta$ is to 0 , the greater is the independence of the central bank in making its choices. And the lower $\lambda^{c b}$, the greater is the degree of conservatism in those choices.

In (9) we have defined the government's inflation target as $\hat{\pi}$. The fact that the same inflation target appears in (10) reflects the situation at the Bank of England, where the bank has instrument independence but not target independence. However, it is easy to relax that assumption and allow the central bank to choose its own target (as the ECB

\footnotetext{
${ }^{20}$ In adopting a linear representation of the output objective, we follow Barro and Gordon (1983). In the monetary delegation literature, the output component in the government's loss function is usually represented as quadratic to reflect an output stability objective. In our model, the quadratic income redistribution term allows monetary and fiscal policy to play a stabilization role as well as pick a position on the economy's output-inflation trade-off.
} 
does). But, as we show in Hughes Hallett and Weymark (2004a), there is no advantage in doing so since the government would simply adjust its parameters to compensate. Hence, only if the Bank is free to choose the value of $\lambda^{c b}$ as well, do we get an extra advantage ${ }^{21}$. Yet even that will not be enough to outweigh the advantages to be gained from fiscal leadership - as we note at the end of this section. Nevertheless, our formulation is the correct one for the UK. The current monetary policy regulations require the Bank of England to achieve a $2 \%$ inflation target - a target which is set by the government - and also to write an open letter, to the government, explaining the reasons for any deviations which are larger than $\pm 1 \%$ around that target and specifying the actions the Bank deems necessary to recover it.

The second feature which is important for British policy, is that (9) and (10) specify symmetric inflation targets around $\hat{\pi}$. Symmetric inflation targets are particularly emphasized as being required of both the Monetary Policy Committee and of the fiscal authorities (HMT 2003). Symmetric output gap targets are also emphasised in the context of fiscal policy, but the Treasury's careful rejection of "formulaic" decision rules for fiscal policy on practical grounds leads us to rely on symmetry in inflation targets to capture this point.

\subsection{The Policy Outcomes}

We characterize the strategic interaction between the government and the central bank as a two-stage non-cooperative game in which the structure of the model and the objective functions are common knowledge. In the first stage, the government chooses the institutional parameters $\delta$ and $\lambda^{c b}$. The second stage is a Stackelberg game in which fiscal policy takes on a leadership role. In this stage, the government and the monetary authority set their policy instruments, given the $\delta$ and $\lambda^{c b}$ values determined at the previous stage. Private agents understand the game and form rational expectations for future prices in the second stage. Formally, the policy game runs thus:

\footnotetext{
${ }^{21}$ In other words, target independence must be defined in terms of priorities as well as targets.
} 


\section{Stage 1}

The government solves the problem:

$$
\begin{gathered}
\min _{\delta, \lambda^{c b}} E L^{g}\left(g_{t}, m_{t} \delta, \lambda^{c b}\right)=E\left\{1 / 2\left[\pi_{t}\left(g_{t}, m_{t}\right)-\hat{\pi}\right]^{2}-\lambda_{1}^{2}\left[y_{t}\left(g_{t}, m_{t}\right)\right]\right\} \\
+\frac{\lambda_{2}^{g}}{2} E\left[(b-\theta) y_{t}\left(g_{t}, m_{t}\right)-\tau_{t}\left(g_{t}, m_{t}\right)\right]^{2}
\end{gathered}
$$

where $L^{g}\left(g_{t}, m_{t}, \delta, \lambda^{c b}\right)$ is (9) evaluated at $\left(g_{t}, m_{t}, \delta, \lambda^{c b}\right)$, and $\mathrm{E}$ denotes expectations.

\section{Stage 2}

1. Private agents form rational expectations about future prices $\pi_{t}^{e}$ before the shocks $u_{t}$ and $\varepsilon_{t}$ are realized.

2. The shocks $u_{t}$ and $\varepsilon_{t}$ are realized and observed by the government and by the central bank.

3. The government chooses $g_{t}$, before $m_{t}$ is chosen by the central bank, to minimize $L^{g}\left(g_{t}, m_{t}, \bar{\delta}, \bar{\lambda}^{c b}\right)$ where $\bar{\delta}$ and $\bar{\lambda}^{c b}$ are at the values determined at stage 1.

4. The central bank then chooses $m_{t}$, taking $g_{t}$ as given, to minimize

$$
\begin{gathered}
L^{c b}\left(g_{t}, m_{t}, \bar{\delta}, \bar{\lambda}^{c b}\right)=\frac{(1-\bar{\delta})}{2}\left[\pi_{t}\left(g_{t}, m_{t}\right)-\hat{\pi}\right]^{2}-(1-\bar{\delta}) \bar{\lambda}^{c b}\left[y_{t}\left(g_{t}, m_{t}\right)\right] \\
+\bar{\delta} L^{g}\left(g_{t}, m_{t}, \bar{\delta}, \bar{\lambda}^{c b}\right)
\end{gathered}
$$

We solve this game by solving the second stage (for the policy choices) first; and then substituting the results back into (11) to determine the optimal operating parameters $\delta$ and $\lambda^{c b}$. From stage 2, we get

$$
\begin{aligned}
\pi_{t}\left(\delta, \lambda^{c b}\right) & =\hat{\pi}+\frac{(1-\delta) \beta(\phi-\eta \Lambda) \lambda^{c b}+\delta(\beta \phi+\gamma \Lambda) \lambda_{1}^{g}}{\alpha[\beta(\phi-\eta \Lambda)+\delta \Lambda(\beta \eta+\gamma)]} \\
y_{t}\left(\delta, \lambda^{c b}\right) & =-u_{t} / \alpha, \\
\tau_{t}\left(\delta, \lambda^{c b}\right) & =\frac{(1-\delta) \beta s(\beta \eta+\gamma)\left(\lambda^{c b}-\lambda_{1}^{g}\right)}{[\beta(\phi-\eta \Lambda)+\delta \Lambda(\beta \eta+\gamma)] \lambda_{2}^{9}}-\frac{(b-\theta) u_{t}}{\alpha} \\
\text { where } \quad \eta \quad \frac{\partial m_{t}}{\partial g_{t}} & =\frac{-\alpha^{2} \gamma \beta s^{2}+\delta \phi \Lambda \lambda_{2}^{g}}{(\alpha \beta s)^{2}+\delta \Lambda^{2} \lambda_{2}^{g}},
\end{aligned}
$$




$$
\phi=1+\alpha \beta-\gamma \theta s,
$$

and

$$
\Lambda=1+\alpha \beta+\beta \theta \text { s. }
$$

Substituting (13)-(15) back into (11) implies we can now get the stage 1 solution from:

$$
\begin{aligned}
& \min _{\delta, x^{c b}} E L^{g}\left(\delta, \lambda^{c b}\right)=\frac{1}{2}\left\{\frac{(1-\delta) \beta(\phi-\eta \Lambda) \lambda^{c b}+\delta(\beta \phi+\gamma \Lambda) \lambda_{1}^{g}}{\alpha[\beta(\phi-\eta \Lambda)+\delta \Lambda(\beta \eta+\gamma)]}\right\}^{2} \\
&+\frac{\lambda_{2}^{g}}{2}\left\{\frac{(1-\delta) \beta s(\beta \eta+\gamma)\left(\lambda^{c b}-\lambda_{1}^{g}\right)}{[\beta(\phi-\eta \Lambda)+\delta \Lambda(\beta \eta+\gamma)] \lambda_{2}^{g}}\right\}^{2} .
\end{aligned}
$$

This part of the problem has first order conditions:

$$
\begin{aligned}
&(1-\delta)(\phi-\eta \Lambda) \lambda_{2}^{g}\left\{(1-\delta) \beta(\phi-\eta \Lambda) \lambda^{c b}+\delta(\beta \phi+\gamma \Lambda) \lambda_{1}^{g}\right\} \\
&-(1-\delta)^{2}(\beta \eta+\gamma)^{2} \alpha^{2} s^{2} \beta\left(\lambda_{1}^{g}-\lambda^{c b}\right)=0
\end{aligned}
$$

and $\left\{(1-\delta) \beta(\phi-\eta \Lambda) \lambda^{c b}+\delta(\beta \phi+\gamma \Lambda) \lambda_{1}^{g}\right\}\left(\lambda_{1}^{g}-\lambda^{c b}\right)\{\delta(1-\delta) \Lambda \Omega+(\phi-\eta \Lambda)\} \lambda_{2}^{g}$

$$
-(1-\delta)(\beta \eta+\gamma) \alpha^{2} s^{2} \beta\{(\beta \eta+\gamma)-(1-\delta) \beta \Omega\}\left(\lambda_{1}^{g}-\lambda^{c b}\right)^{2}=0 .
$$

where $\Omega=\partial \eta / \partial \delta$. There are two real-valued solutions which satisfy this pair of firstorder conditions. ${ }^{22}$ Evidently both are satisfied when $\delta=1$ and $\lambda^{c b}=\lambda_{1}^{g}$. That solution describes a fully dependent central bank, which is not appropriate in the UK case. And, in any event, it is inferior to the solution that follows. The second solution is $\delta=\lambda^{c b}=0$. In this solution, the central bank is fully independent and exclusively concerned with the economy's inflation performance.

Out of these two possibilities, the solution which yields the lowest welfare loss, as measured by the government's (or society's) loss function, can be identified by comparing (19) to the expected loss that would be suffered under the alternative institutional arrangement. Substituting $\delta=1$ and $\lambda^{c b}=\lambda_{1}^{g}$ into (19) results in

\footnotetext{
${ }^{22}$ Because $\eta$ is a function of $\delta,(21)$ is quartic in $\delta$. This polynomial has four distinct roots, of which only two are real-valued. Details of the complete solution may be found in Hughes Hallett and Weymark (2002).
} 


$$
E L^{g}=\frac{\left(\lambda_{1}^{g}\right)^{2}}{2 \alpha^{2}}
$$

But substituting $\delta=\lambda^{c b}=0$ into the right-hand-side of (19) yields

$$
E L^{g}=0
$$

Consequently our results show that, when there is fiscal leadership, society's welfare loss (as measured by (19)) is minimized ${ }^{23}$ when the government appoints independent central bankers who are concerned only with the achievement of a mandated inflation target and completely disregard the impact their policies may have on output.

However, our results also indicate an independent central bank with fiscal leadership will be beneficial under more general conditions. When $\delta=0, \beta \eta+\gamma=0$; the externalities between policy makers are neutralised. As a result, (19) will become

$$
E L^{g}=\frac{1}{2}\left\{\frac{\lambda^{c b}}{\alpha}\right\}^{2}
$$

for any value of $\lambda^{c b}$. Hence an independent central bank will always produce better results than a dependent one so long as it is more conservative than the government $\left(\lambda^{c b}<\lambda_{1}^{g}\right)$, and irrespective of the latter's commitment to social equality $\left(\lambda_{2}^{g}\right)$. A conservative central bank will therefore be best, but any bank more conservative than the government will do.

A more interesting question is whether fiscal leadership with an independent central bank also produces better outcomes, from society's perspective, than those obtained in a simultaneous move game without leadership - as is generally favoured elsewhere in Europe. In the simultaneous move game, the solution to the government's stage 1 minimisation problem is

$$
\delta=\frac{\beta \phi^{2} \lambda^{c b} \lambda_{2}^{g}+\alpha^{2} \gamma^{2} s^{2} \beta\left(\lambda^{c b}-\lambda_{1}^{g}\right)}{\beta \phi^{2} \lambda^{c b} \lambda_{2}^{g}+\alpha^{2} \gamma^{2} \beta\left(\lambda^{c b}-\lambda_{1}^{g}\right)-\phi(\beta \phi+\gamma \Lambda) \lambda_{1}^{g} \lambda_{2}^{g}}
$$

\footnotetext{
${ }^{23}$ This does not necessarily imply that the central banks loss function will be minimized at the same time, although the inflation and output gap results at (29) below suggest that it probably would be.
} 
and society's welfare loss will then be

$$
E L^{g}=\frac{1}{2}\left\{\frac{\lambda_{1}^{g}}{\alpha}\right\}\left\{\frac{(\alpha \gamma s)^{2}}{(\alpha \gamma s)^{2}+\phi^{2} \lambda_{2}^{2}}\right\}
$$

That is always smaller than the loss incurred when fiscal leadership is combined with a dependent central bank. However, the optimal degree of conservatism for an independent central bank, in this case, is obtained by setting $\delta=0$ in (25) to yield:

$$
\lambda^{c b *}=\frac{(\alpha \gamma s)^{2} \lambda_{1}^{g}}{(\alpha \gamma s)^{2}+\phi^{2} \lambda_{2}^{g}}
$$

It is straightforward to show that (24) is always less than (26) as long as

$$
\lambda^{c b}<\left[\lambda_{1}^{g} \lambda^{c b *}\right]^{1 / 2}
$$

It is also evident that $\lambda^{c b *} \leq \lambda_{1}^{g}$ for any value $\lambda_{2}^{g} \geq 0$. Consequently, fiscal leadership with any $\lambda^{c b}<\lambda^{c b *}$ will always produce better outcomes, from society's point of view, than any simultaneous move game between central bank and government. This is an important observation because many inflation targeting regimes, such as those operated by the Bank of England, the Swedish Riksbank, and the Reserve Bank of New Zealand, operate with fiscal leadership; while several others, notably the European Central Bank and the US Federal Reserve System do not. They are better characterized as being engaged in simultaneous move game with their governments.

\subsection{The gains from Fiscal Leadership}

Finally, where do these leadership gains come from? Substituting $\delta=0$ and $\lambda^{c b}=0$ into (13)-(15) yields

$$
\pi_{t}=\hat{\pi}, \quad y_{t}=-u_{t} / \alpha, \quad \text { and } \quad \tau_{t}=-(b-\theta) u_{t} / \alpha
$$

as final outcomes. By contrast, the outcomes for the simultaneous move policy game are

$$
\pi_{t}^{*}=\hat{\pi}+\frac{\alpha(\gamma s)^{2}}{\left[(\alpha \gamma s)^{2}+\phi^{2} \lambda_{2}^{g}\right]}
$$

\footnotetext{
${ }^{24}$ See Hughes Hallett and Weymark $(2002,2004 a)$ for these results.
} 


$$
\begin{aligned}
y_{t}^{*} & =-u_{t} / \alpha \\
\tau_{t}^{*} & =\frac{\gamma s\left(\lambda^{c b *}-\lambda_{1}^{g}\right)}{\phi \lambda_{2}^{g}}-\frac{(b-\theta) u_{t}}{\alpha}
\end{aligned}
$$

Comparing the two sets of outcomes, we can see that fiscal leadership eliminates an inflationary bias and results in lower inflation. Fiscal leadership also yields higher taxes and more income redistribution. ${ }^{25}$ Moreover, these two improvements are achieved with no loss in expected growth. The question is why?

\subsection{The Coordination Effect}

One of the central issues in the coordination literature is whether there are institutional arrangements that yield Pareto improvements over the standard noncooperative outcomes. ${ }^{26}$ When such institutions exist, they may be viewed as a coordination device. In our model, the central bank is independent. Without further institutional restraints that would necessarily lead to noncooperative outcomes. But if the government is committed to long term leadership in the manner we have described, without reducing the bank's independence, the policy game will become an example of rule-based coordination in which performance gains are available for both parties. Given the structure of a Stackelberg game, there will be no incentive to reoptimise for either party - so long as the government remains committed to long term leadership rather than short term demand management - unless both parties agree to reduce their independence through discretionary coordination. ${ }^{27}$ That is a general result: it holds for any model where

\footnotetext{
${ }^{25}$ Note that tax revenues are lower, on average, under the simultaneous move game because $\lambda^{c b}<\lambda_{1}^{g}$. Redistribution is positively related to the amount of tax revenue because $(b-\theta) E y_{t}^{*}=0$, so that $\tau_{t}^{*}$ determines the amount of income redistribution actually achieved: $E \tau^{*}=0$ in (29) vs. $E \tau_{t}^{*} \leq 0$ in (32). The reasons for this result, and the implications for the provision of public services and social equity are discussed in Hughes Hallett and Weymark (2004b).

${ }^{26}$ See, for example: Currie et al (1989), Currie and Levine (1991), Hughes Hallett (1992, 1998), Hughes Hallett and Viegi (2002).

${ }^{27}$ The key point for our results here is that we require no precommitment beyond leadership, and no punishment beyond electoral results. The former holds because governments have a natural commitment to public services (health, education, defence) and some notion of equity or economic efficiency - all long term issues. The latter arises from the political competition inherent in a democracy.
} 
inflation and output both depend on both monetary and fiscal policy, and where inflation is targeted to some degree by both players (Hughes Hallett and Viegi, 2002). Our results are therefore robust. ${ }^{28}$

\subsection{Empirical Evidence}

Whether or not these results are of practical significance is an empirical matter. In Table 3 we have computed the expected losses under the simultaneous move and government leadership regimes for six countries when fiscal policy and the central bank are optimally constructed. The data we have used is from 1998, the year in which the Eurozone was created. The data itself, and its sources, are summarized in the appendix to this paper.

The countries selected fall into two groups:

(a) Eurozone countries: France, Germany, and Italy, and

(b) Non-Eurozone countries with explicit inflation targets: Sweden, New Zealand, and the UK.

In the first group, monetary policy is conducted at the European level, and fiscal policy is conducted at the national level. Policy interactions in this group can be characterized in terms of a simultaneous move game with target as well as instrument independence. The second group of countries has adopted explicit, and mostly publicly announced, inflation targets. Central banks in these countries have been granted instrument independence but not target independence. The government either sets, or helps set, the inflation target value. In each case the government has adopted longer term (supply side) fiscal policies, leaving active demand management to monetary policy. These are clear cases in which there is both fiscal leadership and instrument independence for the central bank.

The results of these calculations are reported in Table 3. Column 1 shows the losses under a dependent central bank in welfare units; leadership or not. Column 2 reflects the

\footnotetext{
${ }^{28}$ But this does not say that both players will gain equally. If the priority for inflation targeting is increased after leadership has been granted, then the leader will gain by less. That is important because it explains why, in a world with inflation targeting, granting leadership to a central bank whose tolerance for inflation is already lower, and pre-commitment already greater, produces no extra gains - although that solution may still be better than that in the simultaneous moves game.
} 
losses that would be incurred under government leadership with an independent central bank that directs monetary policy exclusively towards the achievement of the inflation target (i.e., with $\delta=\lambda^{c b}=0$ ). The third column gives the minimum loss associated with a simultaneous decision-making version of the same game. ${ }^{29}$

\section{Table 3: Expected Losses Under Fiscal Leadership and Other Strategies}

\begin{tabular}{|l|c|c|c|c|}
\hline & $\begin{array}{c}\text { Full } \\
\text { Dependence } \\
\delta=1 \\
\lambda^{c b}=\lambda_{1}^{g}\end{array}$ & $\begin{array}{c}\text { Fiscal } \\
\text { Leadership } \\
\delta=0 \\
\lambda^{c b}=0\end{array}$ & $\begin{array}{c}\text { Simultaneous } \\
\text { Moves } \\
\delta=0 \\
\lambda^{c b}=\lambda^{c b *}\end{array}$ & $\begin{array}{c}\text { Growth Rate } \\
\text { Equivalents } \\
\text { Lost } \\
\%\end{array}$ \\
\hline France & 5.78 & 0.00 & 0.0125 & 1.26 \\
Germany & 16.14 & 0.00 & 0.0079 & 0.79 \\
Italy & 1.28 & 0.00 & 0.0116 & 1.16 \\
\hline Sweden & 4.51 & 0.00 & 0.0098 & 0.98 \\
New Zealand & 8.40 & 0.00 & 0.0104 & 1.04 \\
UK & 3.37 & 0.00 & 0.0113 & 1.13 \\
\hline
\end{tabular}

Evidently, complete dependence in monetary policy is extremely unfavourable although the magnitude of the loss varies considerably from country to country. The losses in column three appear to be relatively small compared to those in column two. However, when these figures are converted into "growth rate equivalents", we find that these losses to be significant. A growth rate equivalent is the loss in output growth that would produce the same welfare loss if all other variables remain fixed at their optimized values. ${ }^{30}$

\footnotetext{
${ }^{29}$ The losses reported in column 3 were calculated using $\lambda_{1}^{g}=1$ and $\lambda_{2}^{g}=0.5$ for each of the six countries in the sample.

${ }^{30}$ Currie et al (1989), Oudiz and Sachs (1984). To obtain these figures we compute the marginal rates of transformation around each government's indifference curve to find the change in output growth, $d y_{t}$, that yields the welfare loss in column three. Formally,

$d y_{t}=\frac{d E L_{t}^{g}}{\left[\lambda_{2}^{g}\left\{(b-\theta) y_{t}-\tau_{t}\right\}(b-\theta)-\lambda_{1}^{g}\right]}$
} 
The figures in column four show that the losses associated with simultaneous decisionmaking are equivalent to having permanent reductions of around 1 percent in the long term growth rate of national income. That is, Germany, France and Italy could have expected to have grown about 1\% faster (or double their 2003 growth rates) had they had this regime; and Sweden, the UK and New Zealand 1\% slower had they not done so. These are significant changes and are equivalent to two thirds of the gains that might have been expected from international coordination (Currie et al, 1989), or from the European single currency itself (EC, 1990).

\section{Conclusions}

a) Fiscal leadership leads to improved outcomes because it implies a degree of coordination and reduced conflicts between institutions, without the central bank having to lose its ability to act independently. This places the outcomes somewhere between the superior but discretionary policies of complete cooperation; and the noncooperative but inferior policies of complete independence.

b) These results show that the important property for monetary policy is instrument independence. Given that, target independence brings few additional gains and may have the effect of undoing the complimentarity between fiscal and monetary policies.

c) The UK appears, both from her institutional structure and the available empirical evidence, to have adopted this leadership framework since 1997. This is perhaps the main reason for her improved performance both in terms of outcomes, and in making more effective use of her fiscal and monetary instruments.

d) Although it is hard to get definitive results from direct tests, the incentive to adopt fiscal leadership is clear from the theoretical results. Confirmation of those results then comes from the outcomes. The leadership with separation model predicts improvements in growth, inflation or income distribution of the order of $1 \%$ of GDP. And that is exact what we have observed since 2000. In addition, the leadership framework requires less

using (9). The minimum value of $d y_{t}$ is therefore attained when tax revenues $\tau_{t}$ grow at the same rate as the redistribution target $(b-\theta) y_{t}$. These are the losses reported in column four. 
precision of information for setting the strategic and institutional parameters, than other strategies. It is easier to implement.

\section{References}

Barro, R.J. (1981), “Output Effects of Government Purchases”, Journal of Political Economy 89, 1086-1121.

Barro, R.J. and D.B. Gordon (1983), "Rules, Discretion, and Reputation in a Model of Monetary Policy", Journal of Monetary Economics 12, 101-21.

Basar T (1989) "Time Consistency and Robustness of Equilibria in Non-Cooperative Dynamic Games" in F van der Ploeg and A de Zeeuw (eds) "Dynamic Policy Games in Economics", p9-54, North Holland, Amsterdam.

Basar T and G Olsder (1999) "Dynamic Noncooperative Game Theory", SIAM series "Classics in Applied Mathematics”, SIAM, Philadelphia.

Brandsma A and A Hughes Hallett (1984)"'Economic Conflict and the Solution of Dynamic Games” European Economic Review, 26, 13-32.

Buti M,S Eijffinger and D Franco (2003) "Revisiting the Stability and Growth Pact: Grand Design or Internal Adjustment?" Discussion Paper 3692, Centre for Economic Policy Research, London.

Canzoneri M "Coordination of Monetary and Fiscal Policy in the Euro Area" Empirica, forthcoming.

Clarida, R., J. Gali and M. Gertler (1998), "Monetary Rules in Practice: Some International Evidence", European Economic Review, 42, 1033-67.

Currie, D.A., G. Holtham and A. Hughes Hallett (1989), "The Theory and Practice of International Economic Policy Coordination: Does Coordination Pay?" in R. Bryant, D. Currie, J. Frenkel, P. Masson, and R. Portes (eds) Macroeconomic Policies in an Interdependent World, International Monetary Fund, Washington DC.

Currie D and P Levine (1991) "The international Coordination of Monetary Policy: A Survey" in C Green and D Llewellyn (eds), Surveys in Monetary Economics, Vol I, Blackwell and Co, Oxford.

Dieppe A, K Kuster and P McAdam (2004) "Optimal Monetary Policy Rules for the Euro Area: an analysis using the Area Wide Model" Working Paper 360, European Central Bank, Frankfurt.

Dixit A (2001)"Games of Monetary and Fiscal Interactions in the EMU", European Economic Review, 45, 589-613.

Dixit, A.K. and L. Lambertini (2003), "Interactions of Commitment and Discretion in Monetary and Fiscal Issues" American Economic Review, 93,1522-42.

Dow, J.C.R. (1964), “The Management of the British Economy 1945-60”, Cambridge University Press, Cambridge.

EC (1990), "One Market, One Money", European Economy No 44, EU Official Publications, Luxembourg.

Fatas, A., J. von Hagen, A. Hughes Hallett, R. Strauch and A. Sibert (2003), "Stability and Growth in Europe", Centre for Economic Policy Research (MEI-13), London.

Gali J and R Perotti (2003)"Fiscal Policy and Monetary Integration in Europe" Economic Policy, 37, 533-71. 
Gerdesmeier, D. and B. Roffia (2003), "Empirical Estimates of Reaction Functions for the Euro Area", WP 206, European Central Bank, Frankfurt.

Gerlach, S. and G. Schnabel (2000), "The Taylor Rule and Interest Rates in the Euro Area", Economics Letters 67, 165-71.

HM Treasury (HMT, 2003), "Fiscal Stabilisation and EMU”,HM Stationary Office, Cmnd 799373, Norwich; also available from www.hm-treasury.gov.uk.

Hatten, T.J. and A. Chrystal (1991), "The Budget and Fiscal Policy" in Crafts, N. and N. Woodward (eds) "The British Economy since 1945” Oxford University Press, Oxford.

Hughes Hallett A (1984)"Noncooperative Strategies for Dynamic Policy Games and the Problem of Time Inconsistency", Oxford Economic Papers, 36, 381-99.

Hughes Hallett A (1992) "Target Zones and International Policy Coordination" European Economic Review, 36,893-914.

Hughes Hallett A (1998) "When Do Target Zones Work?" Open Economies Review, 9, 115-38.

Hughes Hallett, A. and D. Weymark (2002), "Government Leadership and Central Bank Design”, Discussion Paper 3395, Centre for Economic Research, London.

Hughes Hallett A and N Viegi (2002) "Inflation Targeting as a Coordination Device" Open Economies Review, 13, 341-62.

Hughes Hallett, A. and D. Weymark (2004a), "Policy Games and the Optimal Design of Central Banks" in P. Minford (ed), Money Matters, Edward Elgar, London.

Hughes Hallett, A. and D. Weymark (2004b), "Independent Monetary Policies and Social Equity”, Economics Letters 85, 103-10.

Hughes Hallett, A. and D. Weymark (2004c), "Independence before Conservatism: Transparency, Politics and Central Bank Design", German Economic Review, forthcoming.

Lucas, R.E. (1972), "Expectations and the Neutrality of Money", Journal of Economic Theory 4, 103-24.

Lucas, R.E. (1973), "Some International Evidence on Output-Inflation Trade-Offs", American Economic Review 63, 326-34.

McCallum, B.T. (1989) Monetary Economics: Theory and Policy, Macmillan, New York.

Oudiz, G. and J. Sachs (1984), "Macroeconomic Policy Coordination Among the Industrial Economies", Brookings Papers on Economic Activity 1, 1-64.

Plowden Report (1961), "Report of Committee in Control of Public Expenditure" Command 1432, HMSO, London.

Prest, A.R. (1968), "Sense and Nonsense in Budgetary Policy", Economic Journal 71, 118.

Price, R.W.R. (1978), "Budgetary Policy” in Blackaby, F.T. (ed) British Economic Policy 1960-74”, Cambridge University Press, Cambridge.

Radcliffe Report (1959), "Committee on the Working of the Monetary System Report" Command 827, HMSO, London.

Svensson, L. (2003), "What is Wrong With Taylor Rules? Using Judgement in Monetary Rules Through Targeting Rules", Journal of Economic Literature 41, 426-77.

Taylor, J.B. (1993a), Macroeconomic Policy in a World Economy: From Econometric Design to Practical Operation, W.W. Norton and Company, New York. 
Taylor, J.B. (1993b), "Discretion vs. Policy Rules in Practice", Carnegie-Rochester Conference Series on Public Policy 39, 195-214.

Taylor, J.B. (2000), "Discretionary Fiscal Policies", Journal of Economic Perspectives $14,1-23$.

Turrini A and J in 't Veld (2004)" The Impact of the EU Fiscal Framework on Economic Activity" European Commission, DGII, Brussels.

Woodford, M. (2003), Interest and Prices: Foundations of the Theory of Monetary Policy, Princeton University Press, Princeton.

\section{Appendix: Data Sources for Table 3}

The data values used in table 3 are set out in the table below. They come from different sources and represent best practice estimates of the relevant parameters

The Phillips curve parameter, $\alpha$, is the inverse of the annualised sacrifice ratios on quarterly data from 1971-1998 by Turner and Seghezza (1999) the OECD. The values for $\beta$ and $\gamma$, the impact multipliers for fiscal and monetary policy respectively, are the one year simulated multipliers for those policies in Taylor's multi-country model (Taylor, 1993). The national savings ratios, $s$, were obtained from OECD data (Economic Outlook, various issues). I have used 1998 figures since that was the year that EMU started, and the year that new fiscal and monetary regimes took effect in the UK. I also use 1998 to set $\theta$, the desired level of income inequality. Since $\theta$ measures the desired proportion of national income accruing to the rich, it is set at one minus the proportion of fiscal expenditures allocated to social programmes in each country. Finally, I have set $\lambda_{1}^{g}=1$ and $\lambda_{2}^{g}=0.5$ in each country. The value of $\varphi$ follows from there.

\begin{tabular}{|l|l|l|c|c|c|c|}
\hline & $\alpha$ & $\beta$ & $\gamma$ & $\mathrm{s}$ & $\theta$ & $\varphi$ \\
\hline France & 0.294 & 0.500 & 0.570 & 0.211 & 0.620 & 1.072 \\
Germany & 0.176 & 0.533 & 0.430 & 0.216 & 0.583 & 1.040 \\
Italy & 0.625 & 0.433 & 0.600 & 0.214 & 0.651 & 1.187 \\
\hline Sweden & 0.333 & 0.489 & 0.533 & 0.206 & 0.504 & 1.107 \\
NZ & 0.244 & 0.400 & 0.850 & 0.124 & 0.596 & 1.035 \\
UK & 0.385 & 0.133 & 0.580 & 0.180 & 0.675 & 0.980 \\
\hline
\end{tabular}




\title{
CESifo Working Paper Series
}

\author{
(for full list see www.cesifo.de)
}

1309 John Bishop and Ferran Mane, Educational Reform and Disadvantaged Students: Are They Better Off or Worse Off?, October 2004

1310 Alfredo Schclarek, Consumption and Keynesian Fiscal Policy, October 2004

1311 Wolfram F. Richter, Efficiency Effects of Tax Deductions for Work-Related Expenses, October 2004

1312 Franco Mariuzzo, Patrick Paul Walsh and Ciara Whelan, EU Merger Control in Differentiated Product Industries, October 2004

1313 Kurt Schmidheiny, Income Segregation and Local Progressive Taxation: Empirical Evidence from Switzerland, October 2004

1314 David S. Evans, Andrei Hagiu and Richard Schmalensee, A Survey of the Economic Role of Software Platforms in Computer-Based Industries, October 2004

1315 Frank Riedel and Elmar Wolfstetter, Immediate Demand Reduction in Simultaneous Ascending Bid Auctions, October 2004

1316 Patricia Crifo and Jean-Louis Rullière, Incentives and Anonymity Principle: Crowding Out Toward Users, October 2004

1317 Attila Ambrus and Rossella Argenziano, Network Markets and Consumers Coordination, October 2004

1318 Margarita Katsimi and Thomas Moutos, Monopoly, Inequality and Redistribution Via the Public Provision of Private Goods, October 2004

1319 Jens Josephson and Karl Wärneryd, Long-Run Selection and the Work Ethic, October 2004

1320 Jan K. Brueckner and Oleg Smirnov, Workings of the Melting Pot: Social Networks and the Evolution of Population Attributes, October 2004

1321 Thomas Fuchs and Ludger Wößmann, Computers and Student Learning: Bivariate and Multivariate Evidence on the Availability and Use of Computers at Home and at School, November 2004

1322 Alberto Bisin, Piero Gottardi and Adriano A. Rampini, Managerial Hedging and Portfolio Monitoring, November 2004

1323 Cecilia García-Peñalosa and Jean-François Wen, Redistribution and Occupational Choice in a Schumpeterian Growth Model, November 2004 
1324 William Martin and Robert Rowthorn, Will Stability Last?, November 2004

1325 Jianpei Li and Elmar Wolfstetter, Partnership Dissolution, Complementarity, and Investment Incentives, November 2004

1326 Hans Fehr, Sabine Jokisch and Laurence J. Kotlikoff, Fertility, Mortality, and the Developed World's Demographic Transition, November 2004

1327 Adam Elbourne and Jakob de Haan, Asymmetric Monetary Transmission in EMU: The Robustness of VAR Conclusions and Cecchetti's Legal Family Theory, November 2004

1328 Karel-Jan Alsem, Steven Brakman, Lex Hoogduin and Gerard Kuper, The Impact of Newspapers on Consumer Confidence: Does Spin Bias Exist?, November 2004

1329 Chiona Balfoussia and Mike Wickens, Macroeconomic Sources of Risk in the Term Structure, November 2004

1330 Ludger Wößmann, The Effect Heterogeneity of Central Exams: Evidence from TIMSS, TIMSS-Repeat and PISA, November 2004

1331 M. Hashem Pesaran, Estimation and Inference in Large Heterogeneous Panels with a Multifactor Error Structure, November 2004

1332 Maarten C. W. Janssen, José Luis Moraga-González and Matthijs R. Wildenbeest, A Note on Costly Sequential Search and Oligopoly Pricing, November 2004

1333 Martin Peitz and Patrick Waelbroeck, An Economist's Guide to Digital Music, November 2004

1334 Biswa N. Bhattacharyay and Prabir De, Promotion of Trade, Investment and Infrastructure Development between China and India: The Case of Southwest China and East and Northeast India, November 2004

1335 Lutz Hendricks, Why Does Educational Attainment Differ Across U.S. States?, November 2004

1336 Jay Pil Choi, Antitrust Analysis of Tying Arrangements, November 2004

1337 Rafael Lalive, Jan C. van Ours and Josef Zweimueller, How Changes in Financial Incentives Affect the Duration of Unemployment, November 2004

1338 Robert Woods, Fiscal Stabilisation and EMU, November 2004

1339 Rainald Borck and Matthias Wrede, Political Economy of Commuting Subsidies, November 2004

1340 Marcel Gérard, Combining Dutch Presumptive Capital Income Tax and US Qualified Intermediaries to Set Forth a New System of International Savings Taxation, November 2004 
1341 Bruno S. Frey, Simon Luechinger and Alois Stutzer, Calculating Tragedy: Assessing the Costs of Terrorism, November 2004

1342 Johannes Becker and Clemens Fuest, A Backward Looking Measure of the Effective Marginal Tax Burden on Investment, November 2004

1343 Heikki Kauppi, Erkki Koskela and Rune Stenbacka, Equilibrium Unemployment and Capital Intensity Under Product and Labor Market Imperfections, November 2004

1344 Helge Berger and Till Müller, How Should Large and Small Countries Be Represented in a Currency Union?, November 2004

1345 Bruno Jullien, Two-Sided Markets and Electronic Intermediaries, November 2004

1346 Wolfgang Eggert and Martin Kolmar, Contests with Size Effects, December 2004

1347 Stefan Napel and Mika Widgrén, The Inter-Institutional Distribution of Power in EU Codecision, December 2004

1348 Yin-Wong Cheung and Ulf G. Erlandsson, Exchange Rates and Markov Switching Dynamics, December 2004

1349 Hartmut Egger and Peter Egger, Outsourcing and Trade in a Spatial World, December 2004

1350 Paul Belleflamme and Pierre M. Picard, Piracy and Competition, December 2004

1351 Jon Strand, Public-Good Valuation and Intrafamily Allocation, December 2004

1352 Michael Berlemann, Marcus Dittrich and Gunther Markwardt, The Value of NonBinding Announcements in Public Goods Experiments: Some Theory and Experimental Evidence, December 2004

1353 Camille Cornand and Frank Heinemann, Optimal Degree of Public Information Dissemination, December 2004

1354 Matteo Governatori and Sylvester Eijffinger, Fiscal and Monetary Interaction: The Role of Asymmetries of the Stability and Growth Pact in EMU, December 2004

1355 Fred Ramb and Alfons J. Weichenrieder, Taxes and the Financial Structure of German Inward FDI, December 2004

1356 José Luis Moraga-González and Jean-Marie Viaene, Dumping in Developing and Transition Economies, December 2004

1357 Peter Friedrich, Anita Kaltschütz and Chang Woon Nam, Significance and Determination of Fees for Municipal Finance, December 2004 
1358 M. Hashem Pesaran and Paolo Zaffaroni, Model Averaging and Value-at-Risk Based Evaluation of Large Multi Asset Volatility Models for Risk Management, December 2004

1359 Fwu-Ranq Chang, Optimal Growth and Impatience: A Phase Diagram Analysis, December 2004

1360 Elise S. Brezis and François Crouzet, The Role of Higher Education Institutions: Recruitment of Elites and Economic Growth, December 2004

1361 B. Gabriela Mundaca and Jon Strand, A Risk Allocation Approach to Optimal Exchange Rate Policy, December 2004

1362 Christa Hainz, Quality of Institutions, Credit Markets and Bankruptcy, December 2004

1363 Jerome L. Stein, Optimal Debt and Equilibrium Exchange Rates in a Stochastic Environment: an Overview, December 2004

1364 Frank Heinemann, Rosemarie Nagel and Peter Ockenfels, Measuring Strategic Uncertainty in Coordination Games, December 2004

1365 José Luis Moraga-González and Jean-Marie Viaene, Anti-Dumping, Intra-Industry Trade and Quality Reversals, December 2004

1366 Harry Grubert, Tax Credits, Source Rules, Trade and Electronic Commerce: Behavioral Margins and the Design of International Tax Systems, December 2004

1367 Hans-Werner Sinn, EU Enlargement, Migration and the New Constitution, December 2004

1368 Josef Falkinger, Noncooperative Support of Public Norm Enforcement in Large Societies, December 2004

1369 Panu Poutvaara, Public Education in an Integrated Europe: Studying to Migrate and Teaching to Stay?, December 2004

1370 András Simonovits, Designing Benefit Rules for Flexible Retirement with or without Redistribution, December 2004

1371 Antonis Adam, Macroeconomic Effects of Social Security Privatization in a Small Unionized Economy, December 2004

1372 Andrew Hughes Hallett, Post-Thatcher Fiscal Strategies in the U.K.: An Interpretation, December 2004 